\title{
MIRLET7G Gene
}

National Cancer Institute

\section{Source}

National Cancer Institute. MIRLET7G Gene. NCI Thesaurus. Code C80707.

This gene is involved in the regulation of gene expression and plays a tumor suppressor role in ovarian and lung carcinomas. 